\title{
Continental contribution of suspended sediment to an estuary: Ría de Vigo*
}

\author{
O. PAZOS, M.A. NOMBELA and F. VILAS \\ Dept. of Marine Geosciences and O.T., University of Vigo, Spain. E-mail: mnomblea@uvigo.es
}

\begin{abstract}
SUMMARY: Five rivers that flow into the Ría de Vigo were sampled during a period of 2 years from January 1995 to February 1997. Their catchment area approximates $45.3 \%$ of the total drainage into the Ría de Vigo. Flow rates and suspended matter (sm) data were recorded to calculate the volume of runoff. The mineralogy was studied using XRD. Three of the five rivers had been previously sampled during a period of one and a half years, from 1987 to 1989, permitting the comparison of data then and now. The results show low contributions of suspended matter from the rivers but that anthropogenic (land use and forest fires) factors have a direct influence on the increase of suspended matter. The mineralogy is very similar in all five rivers without any appreciable seasonal change, although an increase in the amount of gibbsite was found during periods of unusual erosion.
\end{abstract}

Key words: Suspended sediment, rías, erosion, continental contribution.

\section{INTRODUCTION}

Many studies exist on the fresh-water runoff into the Ría and most of them were undertaken to investigate the influence of such discharges on oceanic environment. The average or estimated flow rates for the principal rivers of the region can be obtained from many existing studies (Prego et al., 1990; Ríos et al., 1992; Río Barja and Rodríguez, 1992). However, suspended matter data for the same rivers is very poor and just two long term studies exist (Nombela, 1989; Alejo, 1994). The flow rates and suspended matter data were collected during two years (1995-97), on a weekly basis, for the five rivers discharging into the Ría de Vigo (Fig. 1), with the aim of quantifying the supply of suspended matter from the continent to the Ría. Three of these

\footnotetext{
*Received January 28, 1998. Accepted February 15, 2000.
}

rivers had already been sampled during 1987-89 (Nombela, 1989) and data from both periods were compared and used in the calculations.

The drainage network in the four Rías Bajas share the same geomorphological characteristics which condition the sedimentary and hydrografic processes. The main channels flow into the internal zones of the Rías and continue flowing in the direction of the drowned valley. Therefore, these rivers constitute the principal sources of sediment load and fresh-water to the Rías. However, there also exist smaller channels, perpendicular to the axis of the Rías, generally in a North-South direction and with minimal flow rates.

The climate in the region is mild and humid. There exists a moderate temperature difference between the summer and winter months. The rainfall difference between the summer and winter increases towards the western part (Carballeira et 


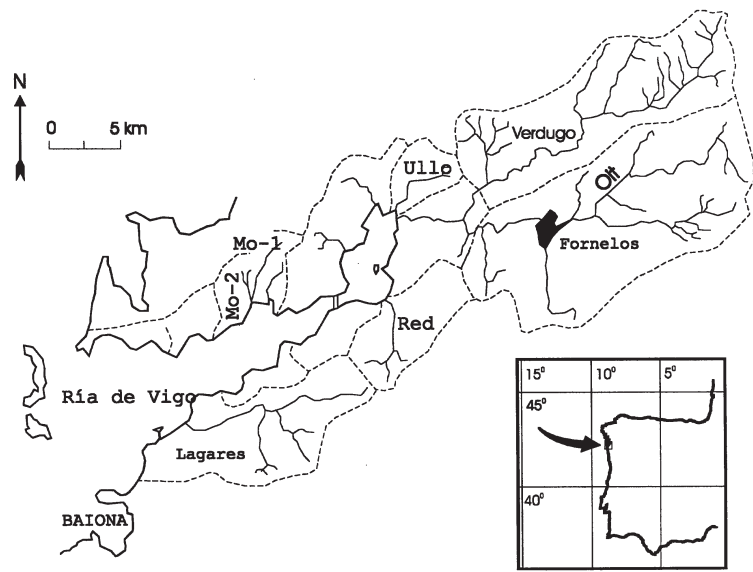

FIG. 1. - Drainage system in the Ría de Vigo shows its principal rivers and basins.

al., 1983), especially on the Northern coast. The annual rainfall is between 1700 and $1900 \mathrm{~mm}$ for the greater part of the catchment area, showing a decrease in the Morrazo peninsula (located towards the West) where it falls to $1000 \mathrm{~mm}$. The average temperatures are $18^{\circ} \mathrm{C}$ in the summer and $9.5^{\circ} \mathrm{C}$ in the winter (Pérez-Alberti, 1982).

\section{The catchment area of the Ría de Vigo}

The catchment area of the Ría de Vigo is $\mathbf{5 7 8 . 2}$ $\mathrm{km}^{2}$. Seventy-five percent of this is discharged into the San Simón Creek, which is linked to the rest of the Ría de Vigo via the Rande Straits. The bigger rivers Oitabén and Verdugo fuse just before emptying into the Creek and themselves constitute about $57.3 \%$ of the total catchment area and thus the principal source of freshwater into the Ría. The River Oitabén flow is regulated by a small dam (the Fornelos Dam). The remaining area is divided into little sub-catchment areas, where the northern coast is more compartmentalised than the southern part, and where the two second big rivers; the Redondela and Lagares are found.

The selection criteria for sampling the catchment area were as follows:
- To continue the sampling program initiated by Nombela (1989) in four of the rivers from the Ría de Vigo, in order to obtain a wider seasonal domain and to verify the accuracy of the obtained data.

- The selected rivers had to represent the drainage runoff spectrum into the Ría, as well as possible.

Following the above criteria, five rivers discharging into the Ría de Vigo were selected. Three of them; the Redondela, the Oitabén and the Ullo (Red, Oit, and Ullo from now on) had been previously sampled on a fortnightly basis from 1987 to 1989. Although the River Oitabén flow is controlled, its behaviour is similar to the River Verdugo (Nombela et al., 1989), therefore it was decided to study just one of them. In addition to sampling the above three rivers, the River Fraga and the River Inferno (Mo-1 and Mo-2 from now on), two little rivers situated on the northern coast of the Ría, which terminate in a delta at their mouth were also sampled.

The characteristics of each of the river catchment areas is as shown in Table 1. The surface data and land use data for each of the catchment areas were obtained from cartographic maps, scale 1:25,000 from the Instituto Geográfico Nacional (1979). The relationship between the biggest and smallest catchment areas is 1:50. In as far as land use is concerned, Mo-2 and Red have large cultivated areas, approximately $43 \%$ while the other rivers are around the $10 \%$ level. The percentage of scrub is variable, between 11 and $71 \%$. The rest of the surface is occupied by forests. The geological substrate is very similar in all of them: gneises and granite.

\section{METHODS}

A gauge station was selected in each river, very near to the river mouth and free of tidal influence. The flow rate was calculated by measuring the average flow velocity and the Transverse Section (TS) of the river. After the first six months of measurements,

TABLE 1. - Main basinal characteristics of the five studied rivers.

\begin{tabular}{lcccccrrr}
\hline & deciduous $(\%)$ & conifers $(\%)$ & cultures $(\%)$ & mix (\%) & scrub (\%) & surface $\left(\mathrm{km}^{2}\right)$ & flow $\left(\mathrm{m}^{3} / \mathrm{s}\right)$ \\
\hline Mo-1 & 2.3 & 0 & 13 & 70.9 & 13.8 & 8.03 & 0.691 \\
Mo-2 & 0 & 0 & 43.1 & 40.1 & 16.8 & 0.43 & 0.701 \\
Ullo & 0 & 4.8 & 8.2 & 33 & 54 & 15.8 & 1.700 \\
Oit & 0.8 & 9.7 & 12.5 & 6 & 11.7 & 55.2 & 0.938 \\
Red & 2.4 & 12.4 & 42.5 & 31.2 & 11.7 & \\
\hline
\end{tabular}


good correlation was obtained between average flows and water levels $\left(\mathrm{P}<10^{-3}\right)$, therefore, this latter data was used directly to calculate flow rates for the rivers Mo-1, Mo-2, Ullo and Red. In the case of the Oitabén, the conversion factors used by the Confederación Hidrográfica del Norte de España for the river were used, without any direct measurements of the riverbed profile or flow velocity.

Suspended matter was determined by filtering approximately one litre of water through Whatman filters of pore size $0.45 \mu \mathrm{m}$ and then calculating the amount by a difference in weight. The collected material was analysed using SEM and XRD for identifying minerals. A 40 kilovolt $\mathrm{CuK} \alpha$ lamp was used and the spectra were taken between $3^{\circ}$ and $70^{\circ}$ with a 10 second pass for every 0.1 degree. In order to discriminate interlayer types we used the standard procedures of glycolation and heating (Moore and Reynolds, 1989).

\section{RESULTS}

The runoff values in the five rivers show a typical seasonal variation, higher in the winter and lower in the summer. The River Oitabén has the highest freshwater discharge of all the five rivers (Fig. 2). The River Mo-2, which has the lowest flow does not show appreciable variations during the year. The part of the river catchment area nearest to the mouth has been modified for irrigation and cultivation purposes and is probably the cause of the slight variations. The background suspended matter values (Fig. 3) are low except for a series of peaks with values 100 times above normal. These

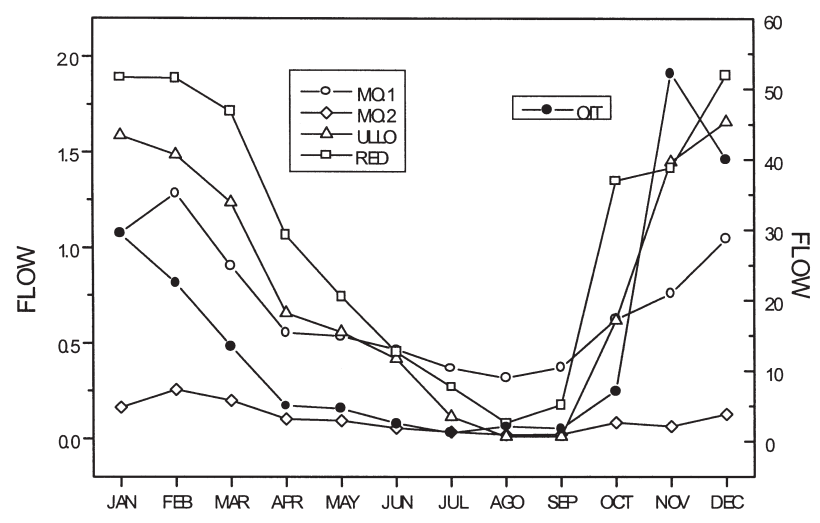

FIG. 2. - Mean flow per month $(\mathrm{m} / \mathrm{s})$ of the five studied rivers. Oitabén river reads on the right axis of the diagram, the others on the left.

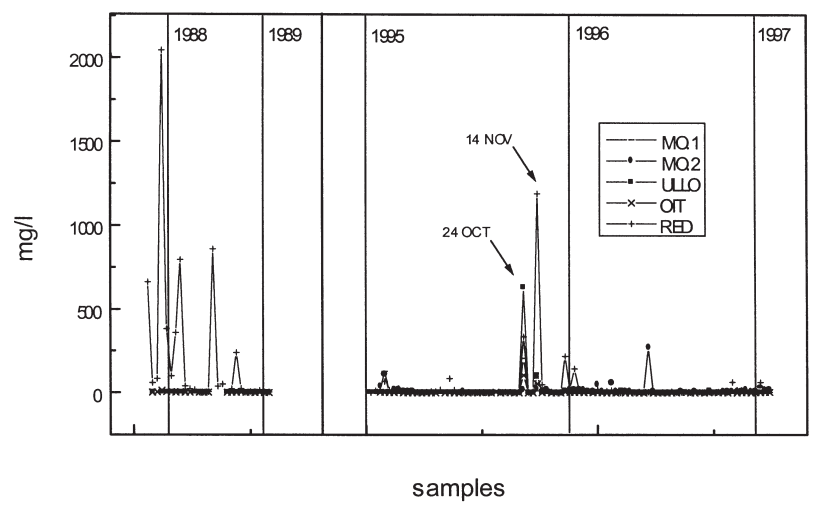

FIG. 3. - Suspension load for the five studied rivers during the two sampling periods. The diagram highlights moments of exceptionally high suspended matter.

abnormal higher values are generally found in the River Red, although they can be seen in the other rivers too. One of these peak values corresponded to the $24^{\text {th }}$ of October, 1995, and could be directly attributed to the washout from burnt areas. This particular sampling coincided with the first torrential rains in the autumn-winter period, after a summer plagued with forest fires in the region. This event affected the catchment areas of the five rivers differently. The River Ullo catchment was the most affected with a value of $634 \mathrm{mg} / \mathrm{l}$ of suspended matter as compared to the normal values of between 1 and $2 \mathrm{mg} / \mathrm{l}$. The river appeared black in colour because of the mixture of ash and earth in the runoff. Three weeks later, on the $14^{\text {th }}$ of November, following another day of torrential rains, the amount of black suspended matter recorded was $100 \mathrm{mg} / \mathrm{l}$.

The bi-variate correlation was performed using flow and suspended matter data. The correlation

TABLE 2. - Caudal and suspended matter (in bold) correlation coefficient values for the studied rivers during 2 year period and four year period. The number of samples is stated in brackets. The numbers in italics indicate that the given values are calculated without the samples obtained on the $24 / 10 / 95$ and the $14 / 10 / 95$. It is known that erosion of burnt soils took place those days.

\begin{tabular}{lllll}
\hline & Mo-2 & Ullo & Oit & Red \\
\hline Mo-1 & $0.8180(88)$ & $0.8652(88)$ & $0.7396(86)$ & $0.7375(87)$ \\
& $\mathbf{0 . 2 0 6 8 ( 8 2 )}$ & $\mathbf{0 . 8 4 4 5}(\mathbf{8 0})$ & $\mathbf{0 . 7 7 1 2 ( 8 2 )}$ & $\mathbf{0 . 2 6 3 1}(\mathbf{8 0})$ \\
Mo-2 & & $0.7449(88)$ & $0.4484(86)$ & $0.6378(87)$ \\
& & $\mathbf{0 . 0 3 2 2 ( 8 2 )}$ & $\mathbf{0 . 0 6 4 9 ( 8 3 )}$ & $\mathbf{0 . 0 6 0 5}(\mathbf{8 2})$ \\
Ullo & & & $0.7779(86)$ & $0.7793(87)$ \\
& & & $0.7016(106)$ & $0.7620(106)$ \\
& & & $\mathbf{0 . 9 4 3 6 ( 8 4 )}$ & $\mathbf{0 . 3 9 3 6}(\mathbf{8 5})$ \\
Oit & & & & $0.6474(85)$ \\
& & & & $0.6589(106)$ \\
& & & & $\mathbf{0 . 6 6 0 7}(\mathbf{8 3})$ \\
& & & & $\mathbf{0 . 3 9 1 5}(\mathbf{1 0 4})$ \\
\hline
\end{tabular}


TABLE 3. - Correlation coefficient values between SM and caudal for each river. The values were calculated for the period $1995-1997$ with and without the samples of the $24 / 10 / 95$ and the $14 / 10 / 95$. Note that R values greatly improve for the Mo-1, Oit and Ull rivers indicating that those days contain a large percentage of the total variance.

\begin{tabular}{lllll}
\hline & Mo-1 & Mo-2 & Ullo & Oit \\
\hline R caudal-SM & $0.4518(82)$ & $0.2063(84)$ & $0.1546(85)$ & $0.2936(83)$ \\
& $\mathbf{0 . 6 5 4 9 ( 8 0 )}$ & $\mathbf{0 . 2 1 1 3 ( 8 2 )}$ & $\mathbf{0 . 5 6 3 1 ( 8 3 )}$ & $\mathbf{0 . 6 3 9 5}(\mathbf{8 1})$ \\
\hline
\end{tabular}

results (Table 2) of flow data for the three rivers: Mo-1, Ullo and Oitabén show high $\mathrm{R}$ values while upon correlating suspended matter, the River Mo-2 and the River Red show a distinct behaviour when compared to the rest of the rivers, with whom they share low total percentage variance. Additionally, the $\mathrm{R}$ values for the flows remain constant when the observation period is prolonged using data from 1987-89, while the $\mathrm{R}$ values for suspended matter in the River Red when compared with the remaining rivers show big oscillations upon modifying the observation period. This means that although all rivers show a response to the rainfall pattern, each river has its own characteristic response for suspended matter which distinguishes it from the rest.

The correlation between flow rates and suspended matter for each river (Table 3 ) is low to very low in all rivers, and reaching insignificant levels in some of them. This means that there exist factors nonrelated to the flow rates, and therefore to the rainfall index, which controls the major part of the suspended mater $\mathrm{v} / \mathrm{s}$ flow rate variance. If we compare the correlation between suspended matter and flow rates observed during the period 1995-97, and after elimination of data for 24-10-95 and 14-11-95, the R values increase significantly in the rivers Ullo, Oitabén and Mo-1, indicating the unusual nature of these days which account for the greater part of the total variance, thus giving high correlation coefficients for the three. In this case, one can appreciate the non-climatic source of the suspended matter, namely the forest fires. The catchment areas for the River Mo-2 and the River Red were not affected by these fires during the summer of 1995 . The non-climatic variation of suspended matter in these rivers must be explained using other mechanisms. Nombela et al. (1995), attributed this anomalous behaviour of the River Red (which showed higher values of suspended matter during low flow rates) to agricultural activities in the catchment area, basing their observation on the coincidence between the sampled dates and maximal farming activity. Table 2 shows that it is precisely the rivers Red and Mo-2 which show the worst correlation values between flow rates and suspended matter and are those with the highest percentage of agricultural land use (Table 1). Galician villages and especially those in the Rías Bajas are characteristic of high population densities which these farmland areas have to support.

Table 4 shows the influence of human activities, forest fires and land use on the suspended matter in the rivers. For example, in the case of the River Ullo, the suspended matter due to the erosion following forest fires, has increased by a factor of 7 in two years and by a factor of 4 in four years, after a period of just two weeks.

Experimental studies in Galicia (Vega et al, 1982) have estimated that about 2200 tons $/ \mathrm{km}^{2}$ are eroded in the first year following the fires. In areas with moderate fires, the erosion reduces significantly to 150 tons $/ \mathrm{km}^{2}$ for areas with Pinus pinaster (Vega, 1987) and from 14 to 400 tons $/ \mathrm{km}^{2}$ for areas with Eucalyptus (San Roque et al., 1985). Going by the figure of between 5-10 tons $/ \mathrm{km}^{2} /$ year of suspended matter (Díaz Fierros, 1991) for the big Galician rivers, one can gauge the clear importance of this on sedimentation. In relative terms, the River Ullo suspended sediment was 16.5 times higher in 1995 than during 1996, which corresponded to a period without fires. This value is not excessive

TABLE 4. - Mean SM values (in mg/l) calculated for 1987-89 and 1995-97. Values are calculated without the samples of the 24/10/95 and the $14 / 10 / 95$. The mean values of several rivers are very influenced by events (as wildfires) or extension in sampling period.

\begin{tabular}{|c|c|c|c|c|c|c|}
\hline \multicolumn{2}{|c|}{ sampling period } & Mo-1 & Мо-2 & Ullo & Oit & Red \\
\hline wiyhout wildfires & $\begin{array}{l}1995-97 \\
1987-89 ; 1995-97\end{array}$ & 3.80 & 12.21 & $\begin{array}{l}1.88 \\
1.59\end{array}$ & $\begin{array}{l}1.79 \\
2.22\end{array}$ & $\begin{array}{r}14.97 \\
104.49\end{array}$ \\
\hline with wildfires & $\begin{array}{l}1995-97 \\
1987-89 ; 1995-97\end{array}$ & 6.56 & 12.33 & $\begin{array}{r}11.35 \\
7.78\end{array}$ & $\begin{array}{l}3.65 \\
3.38\end{array}$ & $\begin{array}{r}30.00 \\
112.75\end{array}$ \\
\hline
\end{tabular}


TABLE 5. - Erosion susceptibility classes established by Diaz-Fierros and Benito (1991) with a rain simulator and considering soil use and lithology interactions.

\begin{tabular}{lccc}
\hline geologic substrate & & \multicolumn{2}{c}{ soil use } \\
& culture & pasture forest \\
& & & \\
\hline Limestones, anfibolites, gabbros, pelitic schists & $>9,5$ & $2,5-5$ & $2,5-5$ \\
Clayed sediments & $5-9,5$ & $2,5-5$ & $2,5-5$ \\
Granites, granodiorites, migmatites, schists & $5-9,5$ & $1-2,5$ & $1-2,5$ \\
Sandy sediments and sandstones & $2,5-5$ & $<1$ & $<1$ \\
& & & \\
\hline
\end{tabular}

when one compares the figure with that of Helvey (1980): 175 in Washington, or the figure given by Brown (1972): 100 in the Australian Eucalyptus forests. The recuperation period of such burnt land in Galicia is estimated at between 1 and 2 years (Vega, 1987; Díaz Fierros et al., 1987). Benito et al.(1991) estimate that about $80 \%$ of the erosion takes place during the first six months of rainfall after the fires. In the case of the River Ullo, the significant increase in the erosion levels is noted only after autumn 1995, that is the post fires months.

Table 4 also shows important differences in average suspended matter transported by the rivers due to the distinct anthropogenic influence in the catchment areas. When one ignores the fire effect, the rivers Mo-2 and Red show suspended matter levels of between 2-5 times that of Mo-1, Ullo and Oitabén. Díaz-Fierros and Benito (1991) state that the geology and land use are determinant factors which indicate the possible erosion of soils (Table 5). One can observe that the geological substrate of all of the catchment areas is similar, made up mostly of granite and gneises, thus making land use the determinant soil erosion factor.

These authors state that the rate of erosion is 5 times higher in cultivated zones located on granite substratum. However Table 6 shows, that when suspended matter values are taken as an erosion index, the values for the Rivers Red and Mo-2 diminish when compared to the rivers Mo-1, Ullo and Red. River Mo-2 even shows lower values than Mo-1. This is because both Red and Mo-2 have the ratio of runoff $/ \mathrm{km}$ of catchment area about 2 to 5 times less than for other rivers. The reason for this difference is the loss of water due to human activities. In the case of the River Red, the erosion index is tens of times higher than that of other rivers, in spite of its low ratio of runoff $/ \mathrm{km}$ of catchment area. Additionally, this river was unaffected by the fires of summer 1995, therefore the suspended matter maximum for 14-11-95 of $2000 \mathrm{mg} / \mathrm{l}$ must have been due to other
TABLE 6. - SM values of Table 5 expressed as erosion rate in $\mathrm{Tm} / \mathrm{km}^{2}$. The more antrophized rivers reduce their differences due to their smaller flow volume per unit area.

\begin{tabular}{lrrrrr}
\hline & Mo-1 & Mo-2 & Ullo & Oit & Red \\
\hline Without wildfires & 9.21 & 9.11 & 3.47 & 4.97 & 14.99 \\
With wildfires & 15.92 & \multirow{2}{*}{9.20} & 2.52 & 4.76 & 90.96 \\
& & & 12.28 & 7.26 & 98.14 \\
\hline
\end{tabular}

causes. These high values can be compared to the River Lagares whose catchment area is occupied by Vigo city and its suburbs. This river is continuously monitored by the Vigo city council and shows high levels of contamination of all types, giving dry residue values of between 200 and $300 \mathrm{mg} / \mathrm{l}$. The suspended matter in the river in this case is directly related to agricultural activity or with other types of anthropogenic activities, especially that of construction, which implies all types of earth moving.

\section{Composition of the suspended matter}

Twenty-eight spectra were obtained between the $24^{\text {th }}$ of January, 1995 and the $17^{\text {th }}$ of January, 1996, which corresponded to half the number of weeks for the year. The diffraction spectrum was obtained using the same filter that was used for sample collection. The background values due to the filter were eliminated via the program RUFI, using a 51 step window and an average of 17 for the rivers Mo-1, Mo-2 and Red, while a 21 step window and an average of 11 were used for the rivers Oit and Ullo. The spectra were added to obtain a representative spectrum of the mineralogy of the suspended matter from the rivers. The spectra for the months of June, July and August on the one hand and those for December, January and February on the other, were added up to look into the possibility of seasonal variations. Finally, a diffraction spectrum of the eroded materials from the Ullo catchment area, was obtained to mark the event of the summer fires and to compare this value with that of the average diffraction spectrum value.

The analysis shows that the mineralogy of the river borne suspended matter is very similar in all of them, because of the same geological substrate. Kaolin and illite-moscovite are the abundant minerals, followed by quartz, vermiculite, inter-bedded with illite-vermiculite, K-feldspar, Na-feldspar and gibbsite. Fernández and Macías (1989) indicated that kaolin was the thermodynamically most stable 


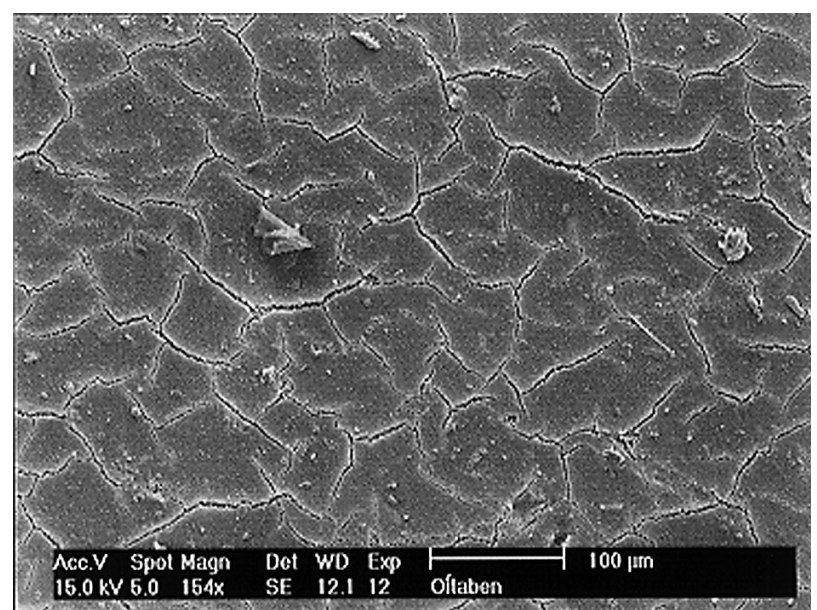

FIG. 4. - SEM image of suspension matter from Oit and Red rivers. The cracked film on the filter is made of algae with mineral particles lying on the top. SEM-EDX analysis showed high iron content in the algae.

mineral in the Galician rivers. Calvo de Anta and Macías (1993) confirmed that kaolin was the decomposition product of feldspar (with long term stability) via an intermediate gibbsite stage.
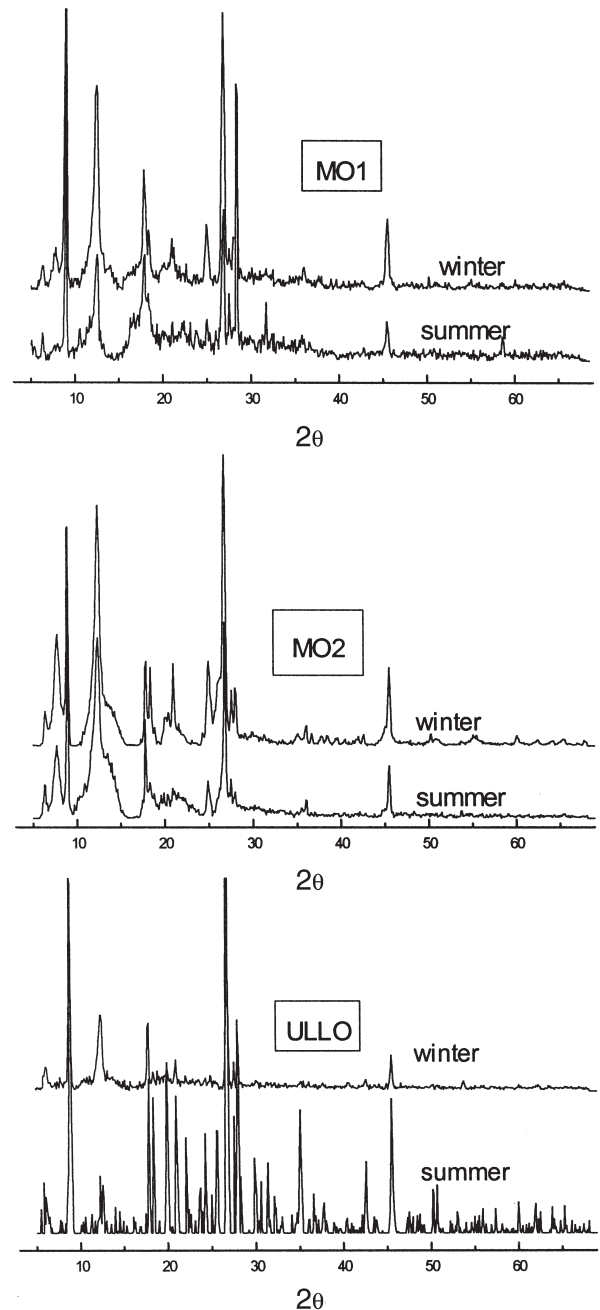

FIG. 5. - XRD diagrams of the samples showed small seasonal differences in their composition.
The rivers discharge both minerals and suspended organic matter into the Rías. In the case of the rivers Ullo and especially the Oit, this microscopic suspended organic matter can be perfectly identified during the filtration process, as it is green in colour and blocks the pores. In the case of the River Oitabén, this vegetable material accounts for almost all of the suspended matter in the river. The diffraction spectra for this river show little signs of crystalline material and upon examination by a Scanning Electron Microscope (SEM), algae and a few minerals in the same proportions as the diatoms are found. The elemental analysis using EDAX highlights the presence of huge amounts of $\mathrm{Fe}$ in these algae (Fig. 4).

The most interesting relationship between the different rivers and their mineralogy is the increase in the relative concentrations of kaolin and vermiculite and inter-bedded material in those rivers with a big agricultural catchment area. These philosilicates are very common in the rivers where the catchment areas
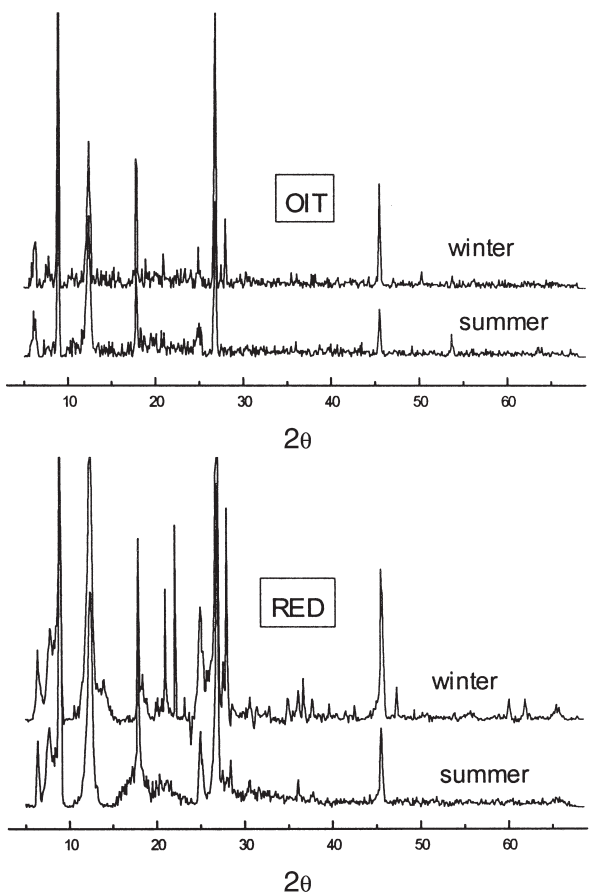


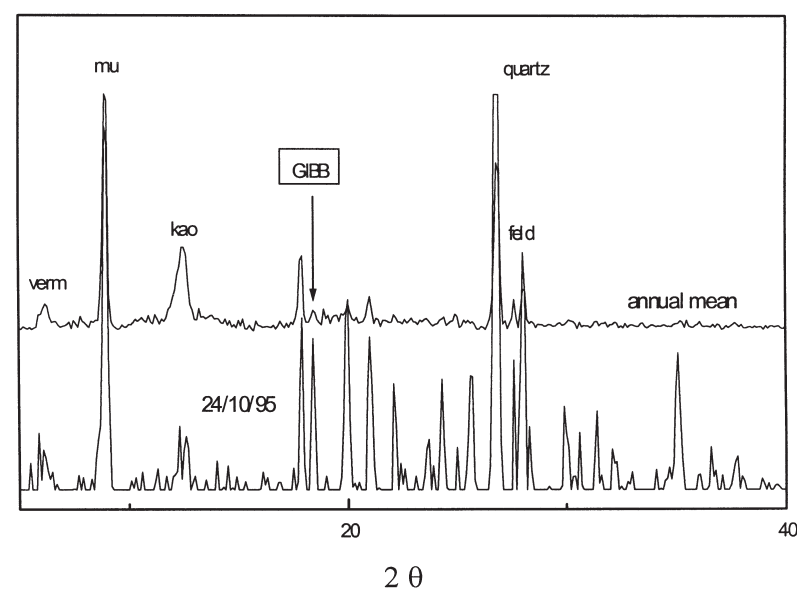

FIG. 6. - XRD for the Ullo river on 24/10/95. The higher gibbsite values than the annual average evidences deep erosion of soils that day.

have a high human impact and could be related to the wide extension of vegetable soils in the area. Although slight differences can be found between the diffraction spectra corresponding to the summer and winter months, there are no apparent common seasonal tendencies (Fig. 5). One can however find a significant mineralogy change in the suspended matter of the River Ullo on 24-10-95. The diffraction spectrum for this day shows an important increase in gibbsite (Fig. 6). Macías (1981) identifies this clay in soils and saprolites, and considers the formation of this clay as an initial plagioclase degradation stage, in soils developed over igneous rocks. This is typical in mountainous regions with incipient soils and its concentration increases with depth reaching its maximum at the horizon $\mathrm{C}$. This clay could therefore be indicative of profound soil erosion and so could serve as a tracer for studying sedimentation in the Rías.

\section{CONCLUSIONS}

The suspended matter values calculated for the rivers studied (except in the case of the River Red) are similar to those calculated by Alejo (1994) for the rivers Miñor and Groba (6.88 and $5.91 \mathrm{mg} / \mathrm{l})$ which empty their contents in Bayona Bay, south of the Ría de Vigo. When the suspended matter values are expressed as an erosion index, they coincide with values obtained by Macías (1991) for the big Galician rivers (5-10 tons $/ \mathrm{km}^{2}$ ). However, from the above paragraphs we can conclude that the continental runoff into the Rías is controlled by anthropogenic activities in the catchment area. Annual rates of between 1-3 tons $/ \mathrm{km}^{2}$ of suspended matter appear to be characteristic of low human intervention areas for rivers discharging into the Ría de Vigo. Higher erosion rates are caused by fires, farming activity or direct dumping. If one studies suspended matter in rivers to calculate the continental runoff, then one must be extremely careful when extrapolating the results for longer time intervals. Tables 5 and 6 show how just 1 or 2 sample data could multiply the final values by a factor of 10 . In the case of the River Red, the presence or not of dumping together with other types of activities in the catchment area could increase the sedimentation rate by a huge factor, thus making just the one river the principal source of sediment into the Ría.

The annual average sediment load of the five rivers discharging into the Ría de Vigo is 4948 tons/year, calculated during the 4 year study in the rivers Oit, Ullo, Red and the 2 year study in the rivers Mo-1 and Mo-2. The catchment area of the five rivers is $261 \mathrm{~km}^{2}$, which corresponds to $45.3 \%$ of the total Ría de Vigo catchment area. If we take into account urban consumption and effluents forecast for the Galician Rías (C.O.T.O.P. 1987), and considering that about 500,000 people live around the Ría de Vigo, one can arrive at an estimate of 30,000 tons/year of suspended matter being dumped into the Ría as domestic sewage. Of the above figure, about $65 \%$ is organic matter (C.O.T.O.P. 1987). These numbers clearly show how anthropogenic activities influence the dumping of suspended matter into the Rías.

The suspended matter shows a similar composition in all five rivers, without any clear seasonal tendency. However, one can appreciate a slight increase in clays, especially kaolin, vermiculite and inter-bedded material in those catchment areas with a high agricultural land use. The gibbsite that appears as a trace element in all of the rivers, increases its proportions in the spectrum for 14-10-95, showing a greater soil erosion at depth. In rivers with a lesser quantity of suspended matter like the Oitabén and Ullo, a greater part of this matter is organic, namely green algae.

\section{ACKNOWLEDGEMENTS}

The authors thank the two anonymous reviewers for the suggestions and reviews to the manuscript which have greatly improved this paper. The paper is a contribution to CICYT MAR95-1953 and MAR 97-0626 projects. We are also thankful to the Xunta de Galicia. 


\section{REFERENCES}

Alejo, I. - 1994. Estudio dinámico y sedimentario de la Bahía de Baiona. Tesis Doctoral. Univ. de Vigo.

Benito, E., B. Soto and F. Díaz-Fierros. -1991. Soil erosion studies in NW Spain. In: M. Sala, J.L. Rubio and J.M. García-Ruiz (eds.): Soil Erosion Studies in Spain, pp. 55-73. Geoforma. Logroño.

Brown, J.A. - 1972. Hydrologic effects of brushfire in a catchment in southern New South Wales. Jour. Hydrol., 15: 77-96.

Calvo de Anta, R. and F. Macías. - 1993. Influence of geological material in the composition of surface waters of Galicia (NW Spain). Genesis of clay minerals. Clay Minerals, 28: 285-296.

Carballeira, A., C. Devesa, R. Retuerto, E. Santillán and F. Ucieda. - 1983. Bioclimatología de Galicia. Fundación Pedro Barrié de la Maza. La Coruña.

C.O.T.O.P. - 1987. Plan de saneamiento para cinco sistemas de rías en Galicia. (Ferrol, a Coruña, Arousa-Umia, Pontevedra y Vigo). Xunta de Galicia. Santiago de Compostela.

Díaz-Fierros, F. - 1991. A conservación do medio físico en Galiza. Cuadernos do Seminario de Sargadelos, 47: 81-108.

Díaz-Fierros, F. and E. Benito. - 1991. Aproximación a una cartografía de la erosionabilidad del suelo en Galicia (NW de España). Cuaternario y Geomorfología, 5: 45-55.

Díaz-Fierros, F., E. Benito and R. Pérez-Moreira. - 1987. Evaluation of the U.S.C.L.E. for the prediction of erosion in burnt areas in Galicia (NW Spain). Catena, 14: 1-11.

Fernández, L. and F. Macías. - 1989. Neoformación de minerales de la arcilla en la España Peninsular: tendencias termodinámicas basadas en la composición de las aguas de los ríos españoles. Cuader. Xeol. Laxe, 14: 19-28.

Helvey, J.A. - 1980. Effects of a North Central Washington wildfire of runnoff and sediment production. Water Resour. Bull., 16 (4): 627-634.

Instituto Geográfico Nacional. - 1979. Mapa Topográfico Nacional de España 1:25.000. Hojas 185 II, IV; 186 I, II, III, IV; 223 II, IV. Madrid.

Macías, F. - 1981. Formation of gibbsite in soils and saprolites of temperate-humid zones. Clays Minerals, 16: 43-52.
Macías, F. - 1991. Materiáis orixináis en solos de Galiza. Cuadernos do Seminario de Sargadelos, 47: 47-79.

Moore, D.M. and R.C, Reynolds. - 1989. X-Ray Diffraction and the Identification and Analysis of Clay Minerals. Oxford University Press. Oxford. 326 pp.

Nombela, M.A.. - 1989. Oceanografía y sedimentología de la Ría de Vigo. Tesis Doctoral, Univ. Complutense.

Nombela M.A., F. Vilas and I. Alejo. - 1989. Balance de las partículas finas que alcanzan la ensenada de san Simón, Ría de Vigo (Galicia). Comunicaciones al XII Congreso Español de Sedimentología. Bilbao. 125-128.

Nombela, M.A., F. Vilas and G. Evans. - 1995. Sedimentation in the mesotidal Rías bajas of Galicia (north-western Spain): Ensenada de san Simón, Inner Ría de Vigo. In: B.W. Flemming and A. Bartholomä (eds.), Tidal Signatures in Modern and Ancient Sediments. pp. 133-149. Blackwell, Oxford.

Pérez-Alberti, A. - 1982. Xeografía de Galicia. Ediciones Sálvora. A Coruña.

Prego, R., F. Fraga, and A. Ríos. - 1990. Water interchange between the Ría of Vigo and the coastal shelf. Sci. Mar., 54(1): 95-100.

Río Barja, F.J. and F. Rodríguez. - 1992. Os ríos galegos. Morfoloxía é Réxime. Consello da Cultura galega. Santiago de Compostela.

Ríos, A., M.A. Nombela, F. Pérez, G. Rosón and F. Fraga. - 1992. Calculation of runoff to an estuary. Ría de Vigo. Sci. Mar., 56(1): 29-33.

San Roque, P., J.L. Rubio and J. Mansanet. - 1985. Efectos de los incendios forestales en las propiedades del suelo, en la composición florística y en la erosión hídrica de zonas forestales en Valencia (España). Rev. Ecol. Biol. Sol., 22(2): 131-147.

Vega, J.A., S. Bara, M.A. Villamuera and M. Alonso. - 1982. Erosión después de un incendio forestal. Dpto. Forestal Zonas Húmedas. 24 pp.

Vega, J.A. - 1987. Wildfire effects on soil erosion. 1987. Dpto. Forestal Zonas Húmedas. 12 pp.

Scient. ed.: A. Palanques 